\title{
MACROECONOMIC VARIABLE AND ITS INFLUENCE ON PERFORMANCE OF INDONESIAN ISLAMIC BANKING
}

\author{
Yoghi Citra Pratama ${ }^{1}$
}

\begin{abstract}
Macroeconomic Variables and Its Influence on Performance of Indonesian Islamic Banking. The purpose of this research is to analyze the macroeconomics variables that affect to the performance of Islamic banks in Indonesia. Methods used in this research is the Vector Auto regressive (VAR) / Vector Error correction model (VECM) to see the effect of the shock and the long-term effect on the performance of Islamic Banking. The results show that based on the analysis of IRF, the performance of Islamic banking having short-term shocks to fluctuations in macroeconomics variables but stable in the long term, and based on the variance decomposition, shocks of macro variables only gives little effect on the performance of Islamic banking.
\end{abstract}

Keywords: Performance, Islamic banking, VAR, Macroeconomic variable

\begin{abstract}
Abstraksi. Pengarub Variabel Makroekonomi Terhadap Kinerja Perbankan Syariab di Indonesia. Tujuan dari penelitian ini adalah untuk menganalisis pengaruh variabel makro ekonomi terhadap kinerja bank syariah di Indonesia. Metode yang digunakan dalam penelitian ini adalah Vector Auto Regresive (VAR)/Vector error correction model (VECM) untuk melihat efek dari shock dan efek jangka panjang terhadap kinerja Perbankan Syariah. Hasil penelitian menunjukkan bahwa berdasarkan analisis IRF, kinerja perbankan syariah memiliki guncangan jangka pendek terhadap fluktuasi variabel makroekonomi tapi stabil dalam jangka panjang, dan berdasarkan dekomposisi varians, guncangan variabel makro hanya memberikan sedikit efek pada kinerja perbankan syariah.
\end{abstract}

Kata Kunci: Kinerja, perbankan Islam, VAR, Variabel makroekonomi

First draft: September, 15th 2014, Revision: November, 30th 2014, Accepted: December, $16^{\text {th }}$ 2014

${ }^{1}$ Syarif Hidayatullah State Islamic University. Jl. Ir. H. Juanda No. 95, Ciputat, South Tangerang, Banten, Indonesia.

Email:yoghi@uinjkt.ac.id 


\section{Introduction}

Globalization and integration of the financial sector in the world economy led to the depedency among countries in the world. Globalization means more corelation among countries especially in connection to world trade and financial market either directly or indirectly, this is proved by the global financial crisis that occurred in 2008, where the financial crisis that began in the United States has effected to the other countries in the world. The 2008 global financial crisis that started in the U.S. in late 2007 has given a wide array of impacts to the operating and financial performance of many banks all over the world. As a result, many banks across the world reported financial loss on their financial reportdue to their connections with subprime mortgage in the U.S. or were simply affected by economic recession in theirown countries.

The impact of the crisis have even forced around 123 banks in the U.S. to file for bankruptcy in theyear, including American giant bank Lehman Brother that was never been expected to fail (Hidayat and Abduh, 2012). Indonesia is also get the impact of global crisis, that can be seen from a number of macroeconomic indicators in Indonesia. The impact of the crisis also approached the financial and banking system in Indonesia, it can be seen from the financial ratios of banks that had a significant correction, including the banking system which uses a sharia based

The development of Islamic banks in Indonesia is growing faster when the government is fully committed in 1998 by issuing Law No. 10 in 1998 to enhance the previous Act, Act 7 of 1992, which provides institutional and operational developments of Islamic banking in a comprehensive manner. With this legislation, dual banking system has been implemented, in which the conventional banks and Islamic banks recognized and both are regulated and supervised by Bank Indonesia. When business unit has enacted Law No. 212008 on the Islamic Banking on July 16, 2008, then as a follow-up mandate of the Act referred to, some new policies must be drawn up and some of the provisions that have been issued by Bank Indonesia should be adjusted to remain focused on six aspects, including adherence to Islamic principles, compliance with prudential aspects, the development of operating efficiency and competitiveness, and system stability benefits to the economy, improving the competence and professionalism of human resources, as well as the optimization of social functioning of Islamic banks in facilitating the voluntary sector / social with people's economic empowerment efforts. (LPPS Bank Indonesia, 2008).

Based on BI data in June 2012, the number of Islamic banks were established 11 the number of bank offices in 1780 , and the number of conventional banks that have Islamic business units are 24and the number of bank offices 521. Coupled 
with rural Islamic banks amounted to 158, the number of office 398. development of Islamic banking assets also increased rapidly and above the average of national banks.

Graph 1. The development of Islamic Banking Assets

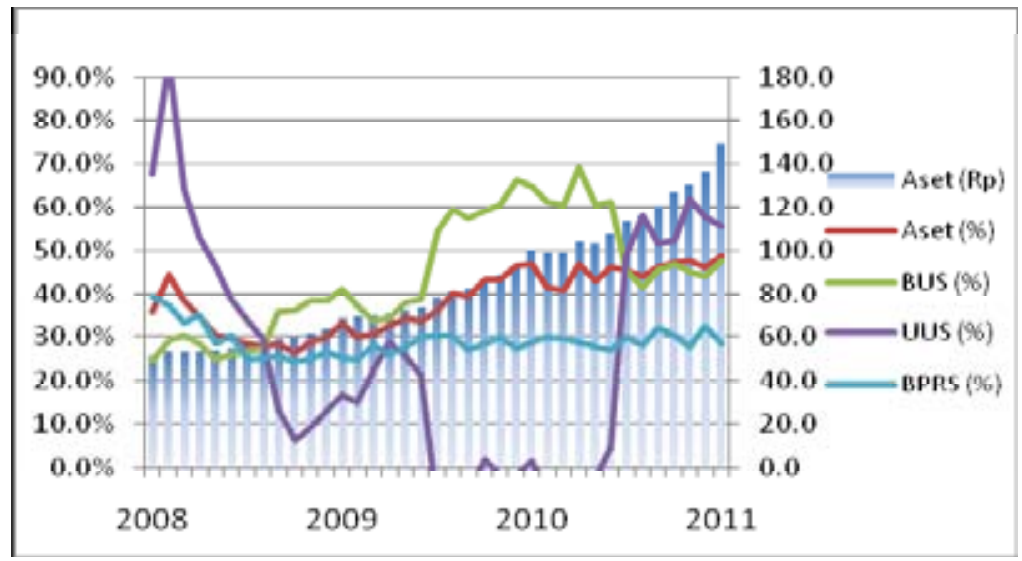

Source: Bank Indonesia

From the graph above can be shown that the development of Islamic banking assets increased significantly from 50 million in 2008 to 150 trillion in 2011 even growth of Islamic banking assets has fluctuated, although still above the average national banks, Islamic banks grow to over $30 \%$ since the year 2008 and reached its peak in 2010, which reached $70 \%$. This illustrates that Islamic finance industry has great potential and is not overly affected by the global financial crisis.

Years 2008 to 2009 was a challenging year for the financial system, both domestically and globally because in that year the world was hit by the global financial crisis. The crisis that began with subprime mortgage in the United States has disrupted the stabilization of the global financial system, the effect is even to countries in Southeast Asia, including Indonesia. Many international and domestic financial institutions have liquidity problems because they are involved too deeply in financial derivatives sector. In addition, the global crisis has also hampered the Indonesian macroeconomic system. Where economic growth declined from $6.3 \%$ at the end of 2007 to $6.1 \%$ in late 2008 and in 2009 was estimated according to Bank Indonesias economic growth will also be corrected to $4.3 \%$. Inflation reached its highest level of the 12.07\% in September 2008, which since 2007 has always been below the range of $10 \%$. Rupiah exchange rate also depreciated against the dollar, to ever reach 12,150 rupiah per dollar in November 2008. 
The global financial crisis also makes $\mathrm{BI}$ as monetary authorities create policies like lowering the interest rate (BI Rate) by 300 basis points since November 2008 to encourage the growth of the real sector. The judging from the characteristics of Islamic banking if interest rates rise, it will suppress the growth of Islamic banking deposits, which in turn will impact on the level of profitability, and vice versa if the interest rates tend to fall in deposits of Islamic banks will increase. Currently September 2009 Bank Indonesia interest rate has dropped to 6.5\% from its highest point of $9.5 \%$ in November 2008.

The crisis that occurred in 2008 is an implication of the loss of the monetary sector linkages with the real sector. Monetary sector has grown so fast through derivative products, cross-country over the edge. The development of the monetary sector so quickly is not matched by the real sector, resulting in an economic bubble. Money becomes a tool commodity is traded with other debt securities, as a result of speculative motives.

The global financial crisis in 2008 tends to slow the pace of economic growth in many countries and lead contraction of macroeconomic indicators. It is expected to have minimal impact on the national Islamic banking industry. There are several reasons why it believed the effect of the global financial crisis in 2008 was not significant to the national Islamic banking industry. First, the concept of sharia-based real sector and based on an underlying asset in the transaction, requires that the monetary sector developed by the real sector. Islamic banking financing portfolio exposure is almost $100 \%$ channeled in the form of business financing in productive sectors (real sector), where the concentration of the business sector financing of Islamic banking is the domestic business sectors that are not directly related to foreign trade (LPPS Bank Indonesia, 2012).

While the quality of Islamic banking financing is still relatively well preserved, as seen from the ratio of the NPF industry several years this is still maintained at an average rate of $3 \%$. And sector financing is minimal from the financing of foreign trade enterprises. This means that the national Islamic banking financing are still dominant in the domestic market. It is because Islamic banking financing capacity is relatively limited. Secondly, the nature guided by the principles of sharia, Islamic banking is not allowed to use products based on interest and speculation. Here are the indicators of financial ratios that show the performance of Islamic banking in 2007-2012.

From the table 1, we see that in general the global financial crisis has not significantly affect the performance of the national Islamic banking, if in view of the growth of financing (loans) of banks or Financing to Deposit Ratio (FDR) is still high with an increasing trend since 2005 to reach $103,65 \%$ in 2008 , with 
the level of financing (credit) problematic or Non Performing Financing (NPF) is still kept below 5\% and experienced a decreasing trend from 2007 to reach $2.22 \%$ by 2012 . This means that Islamic banking still function properly as intermediary, by channeling financing to the real sector. In addition, Islamic banking has a great durability against the global crisis with the NPF rate remains below 5\%.

Table 1. Performance Indicators of Islamic Banking

\begin{tabular}{|c|c|c|c|c|c|c|}
\hline Ratio & 2007 & 2008 & 2009 & 2010 & 2011 & 2012 \\
\hline CAR & $10.67 \%$ & $12.81 \%$ & $10.77 \%$ & 16. $25 \%$ & 16. $63 \%$ & $14.13 \%$ \\
\hline ROA & 2. $07 \%$ & $1.42 \%$ & 1. $48 \%$ & $1.67 \%$ & $1.79 \%$ & 2. $14 \%$ \\
\hline ROE & $40.38 \%$ & $38.79 \%$ & $26.09 \%$ & $17.58 \%$ & $15.73 \%$ & $24.06 \%$ \\
\hline $\mathrm{NPF}$ & $4.05 \%$ & $1.42 \%$ & 4. $01 \%$ & $3.02 \%$ & 2. $52 \%$ & 2. $22 \%$ \\
\hline FDR & $99.76 \%$ & $103.65 \%$ & $89.70 \%$ & $89.67 \%$ & $88.94 \%$ & $100.00 \%$ \\
\hline ВОРО & 76. $54 \%$ & $81.75 \%$ & $84.39 \%$ & $80.54 \%$ & $78.41 \%$ & $74.75 \%$ \\
\hline
\end{tabular}

Source: Bank Indonesia

Based on CAR, Islamic Banking a good performance in capital adequacy ratio. It is about $8 \%$ in 2011 and the highest rate reaches 16.63\%. Thus, the bank should obtain a profit from lending activities (FDR), which continues to increase with the level of non performing financing (NPF), which tends to decrease. However, in the profitability ratio, ie the indicator Return on Assets (ROA) and Return on Equity (ROE) in 2008, ROA is decreasing into $1.42 \%$ compared to $2007 ; 2.07 \%$. Same as $\mathrm{ROE}$ indicator, it's the highest point was $40.38 \%$ in 2007 , and decreased into $15.73 \%$ in 2011 . Then it began to increase up to $24.06 \%$ in 2012 . Based on the above data, the authors are interested to find out the influence of external factors such as macro-economic variables which are contracted due to the impact of the global financial crisis to the performance of Islamic banking. Based on the exposure above, the authors formulate the following research questions.

How does the performance of Islamic banking which are proxy by FDR, CAR, NPF and ROA in the face of a global crisis that is shown by contracted the macroeconomic variables such as SBI interest rate, exchange rate and inflation rate from year 2007-2012?

\section{Literature Review}

Macroeconomic conditions have an important role in the performance of banking. Kunt (2000) describes the factors that determine the occurrence of banking crises that can affect the performance of banking including macroeconomic factors, 
financial, and institutional. Since the early 1980s, macroeconomic problems became systemic problems in the banking sector that has happened in most countries. Vulnerable banking crisis occurs in a weak macroeconomic conditions. Low GDP may increase the risk in banking sector. Vulnerability to shocks on aggregate output is not always a sign that the banking system is not efficient, because the role of banks as financial intermediaries are risk taking. Increased risk in the banking sector is also caused by high levels of inflation. So that the tightening of monetary policy is used to create stability in the banking sector

Second is the financial factor. High real interest is not only caused by stability policy of inflation, but also by others like financial liberalization. The degree of financial liberalization significantly affect the likelihood of a banking crisis even though real interest rates can be controlled. The third is the institutional factor. This factor will focus on internal activities within banking. The existence of deposit insurance schemes tend to increase the likelihood of systemic problems in banking. When on one side of the deposit insurance may reduce any panic in the banking sector, but on the other hand the existence of deposit insurance may lead to moral hazard. Therefore, reduce acts of moral hazard in the implementation of the deposit insurance is a top priority in the banking system.

The affect macroeconomic research on the performance of banks and other financial institution have been carried out in the world today. Bank of England (2003) in the research used the method of estimating and calculating (VAR) found its banking system losses in the face of macroeconomic variable shocks. The Reserve Bank of Australia also collects all of his resources to calculate and identify the relationship between bank profitability and bank resilience to contraction of macroeconomic variables in Australia (see Gizycki, 2001). Athanasoglu and Delis (2005) also studied the effects of fluctuations in macroeconomic variables to the profitability of Islamic banking in Greece, the results show that the inflation as a significant positive affect on the profitability of banks which are proxy by return on equity (ROE) and return on assets (ROA).

In the context of macro economic management, Clair (2004) in his research in Singapore found that on average two-thirds of the bank's performance is closely linked to the performance of macroeconomic variables. Islamic banking has different characteristics from conventional bank, but Islamic banking transactions which based on real sector also can not be separated from economic conditions. In some empirical studies, there are not direct correlation between changes in bank's performances and the business cycle. Both income and expenditure are likely to be pro-cycle where the outcome for profit depends significantly on the banks' expense policy and their credit risk profile. The relationship between risk and return depend 
on how banks price for risk and the lags between taking on risk and the crystalisation of the risk into realised profit or losses. When GDP increases, banks may earn higher returns by taking on greater risk, which boosts profits. However, if a bank suffered a loss, it subsequently beyond what it had provisioned, so the losses will reduce its profitability (Clair, 2004).

The research about the impact of macroeconomic condition to Islamic banking performance have been also carried out in the world today. Hassan and Dridi (2010) compare the performance of Islamic banks (IBs) and conventional banks (CBs) since the recent global crisis by looking at the impact of the crisis on profitability, credit asset growth, and external ratings in a group of countries where the two types of banks have significant market share. The study suggests that IBs have been affected differently than CBs. Those factors related to IBs'business model helped limit the adverse impacton profitability in 2008, while weaknesses in risk management practices in some IBs led to a larger decline in profitability in 2009 compared to CBs. IBs' credit and asset growth better than CBs in the year 2008-09. This contributes the financial and economic stability. Therefore, the external rating agencies're-assessment of IBs' risk was generally more favorable.

Noor and Ahmad (2011) studied the efficiency of the 78 Islamic banks in 25 countries in 1992-2009. The Fixed Effect Model used to examine the impact of operating expenses to assets, equity, high income countries and non performing loans to total loans on profit efficiency. They found that the operating expenses to to the high equity of assets and high income countries, have a positive and significant effect onfinancial performance of Islamic banks. Asma, Fadi and Noor (2011) examined the determinants of profitability of Islamic banks in Malaysia. Number of Islamic banks in specifics variables had been used capital adequacy, and management of expenses credit risk, liquidity, Log total assets. They found that only the bank's size has a positive significant impact on profitability of Malaysian Islamic banks. While the other variables have no impact on Islamic's banks profitability. Bashir (2003) investigated the determinants of profitability for 14 Islamic Banks from 8 Middle Eastern Countries. He found that total equity to total assets, loans to total assets and overhead (salaries, wages, and investment cost) have a positive and significant impact on profitability measured by (ROA), (ROE) and basic earning power. Gross domestic product growth has a positive and significant impact on Islamic banks profitability (Mustafa and Ali, 2013).

\section{Methods}

This research is a descriptive-correlational research (causal) that will explain the relationship of macroeconomic variables ( inflation, interest rates Certificates 
of Bank Indonesia, the rupiah exchange rate against the dollar) and variables of the performance of Islamic Banking which are proxy by CAR, NPF, FDR, and ROA, to know whether those variables have positive or negative influence. Descriptive research is an explanation of the characteristics, profile, and relevant aspects of the phenomenon of the research object (Nachrowi and Usman, 2007).

The data analysis of the study is Vector Auto reggresive (VAR)/Vector Error Correction Model (VECM), which aims to look at short-term relationships and using cointegration test to see indications of the long-term relationship. Analysis of data will be done with the help of computer application programs such as E-views 6.

VECM testing can only be conducted if there are indications of a long-term correlation using cointegration test. The Variables are identified to be cointegrated when stationary at the same order. The Augmented Dickey Fuller (ADF) Test used to test the stasioner data. In the ADF test is done by adding (augmenting) the value of the lag on the dependent variable. Specifically, the ADF test follows the following equation:

$$
\Delta \mathrm{Yt}=\beta 1++\delta \mathrm{Yt} \beta 2 \mathrm{t}-1+\Sigma \alpha \Delta \mathrm{Yt}-1+\varepsilon \mathrm{t}
$$

the study used data natural $\log (\ln )$ of the variables, except for the variables that are already in the unit of percentage, that method is useful for solving the equation. Logs model is a model which states measure the elasticity of Y with respect to $\mathrm{X}$, the size of the percentage change in the percentage change in $\mathrm{Y}$ when $\mathrm{X}$ is known by the model Ln_Y $=\alpha+\beta 1+\varepsilon \ln \_\mathrm{x}$.

Vector Autoregressive (VAR) is used to see the effect of macroeconomic shocks on the performance of the Islamic banking. While the methods of Vector Error Correction Model (VECM) will be used if there are diffrent stationary variables.

\section{Discussion}

In the first stage of data characteristics will be tested using the unit root test. Unit root test is necessary to determine the data according to Gujarati the data become stasioner if the data of the time series data sets (time series data) had an average (mean) and variance are constant over time, except that the value of covariance between two period of time only depends on the distance or lag of two periods of time and does not depend on waktu.Data Exchange in this study in the form of natural logarithm (ln), to simplify the analysis.

The test of stasioner is a major requirement in the cointegration test, if the time series data are not stationary, then the model will have problems unit root, so that the handle unit root test (unit root test). In this study the unit root test is done 
by using Augmented Dickey Fuller test (ADF test). Variable that has a value smaller than its McKinnon then these variables have stationary. Testing the unit root can also be determined by the value of its critical value, if the value of the ADF is larger than the critical value then the variable valuenya Stationary, otherwise if the ADF if indigo is smaller than the value of critical value (CV) $5 \%$ then the data is not stationary. The results of the unit root test can be seen from the following table:

Table 2. Augmented Dickey Fuller test (First Diffrencing)

\begin{tabular}{lllll}
\hline No. & Variables & ADF test & CV 5\% & $\begin{array}{l}\text { Ho }=\text { There is a stationary } \\
\text { Ha }=\text { Stationary }\end{array}$ \\
\hline 1 & CAR & -7.018919 & -2.954021 & Stationary \\
2 & FDR & -7.143259 & -2.951125 & Stationary \\
3 & NPF & -7.704743 & -2.951125 & Stationary \\
4 & ROA & -8.973787 & -2.951125 & Stationary \\
5 & SBI & -3.461580 & -2.951125 & Stationary \\
6 & INFLATION & -3.765297 & -2.951125 & Stationary \\
7 & EXCHANGE & -5.339399 & -2.951125 & Stationary \\
\hline
\end{tabular}

Results of stationarity test data showed no variables are stationary at level. Therefore variables derived in first-degree diffrencing, as listed in the table above. The next stage is the determination of the optimal lag. Determination of the optimal lag is very important because the independent variable used is nothing but a lag of endogenous variables. Determination of the optimal lag is done based on the value of Schwartz information criterion (AIC). Selection of optimal lag cointegration test done before, it is important to do before estimating Vector Autoregressive (VAR) model. Election lag length is important because it can affect the acceptance and rejection of the null hypothesis, resulting in biased estimates and could result in inaccurate predictions.

\section{Graph 2. Impulse Response Function On CAR}

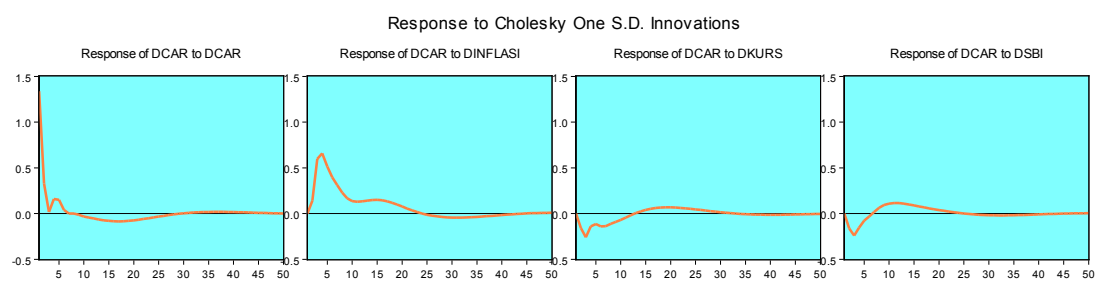

The longer the lag is used to reduce the degree of freedom and the number of observations, while the amount of lag that is too short will result in incorrect 
specification (Gujarati, 2007). The issue of the selection of lag length also increased with the assumption that the selection of the appropriate lag will result in residual (free from autocorrelation and hetroskedastisitas) (Gujarati, 2007). To define the optimal lag value typically used Akaike information criteria (AIC), Final Prediction Error (FPE), Hannan-Quinn Information Criterion (HQ) and Schwarz Information Criteria (SC).

In this study the magnitude of the lag is selected based on the value of the smallest SC. SC calculations every lag. From the test results it is known that CAR models, FDR, NPF and ROA indicates optimal lag one, is evident from the value Schawart Information Criteria and Hannan-Quinn Information that shows the smallest value in lag 1 .

\section{Graph 3. Impulse Response Function On FDR}

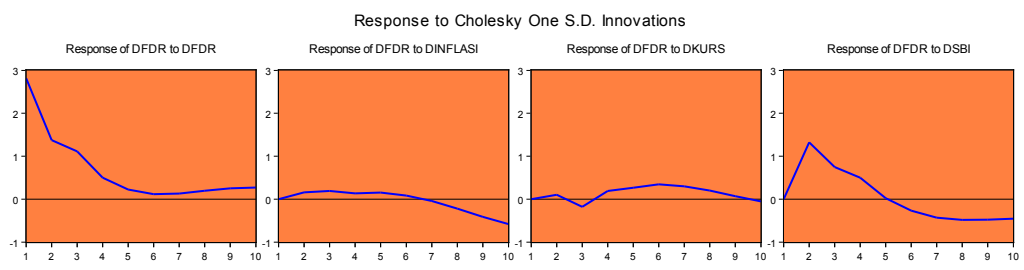

From the graph 2, it is known that the impulse respone function test results showed that the CAR response to inflation shock. Seen from the table above it can be seen that CAR responds positive to inflation shock until at 25 th period, after it fluctuates into a negative and stable at zero in the long run in the 40th period. CAR response to fluctuations in the exchange rate is negative at 15 th period after having a positive movement in the short term and having stability at 35 th period. Firstly CAR response to SBI with fluctuates and have negative relationship at eight period after that in the short term CAR responds positively and achieve stable movement began at 25 th period.

\section{Graph 4. Impulse Response Function On NPF}

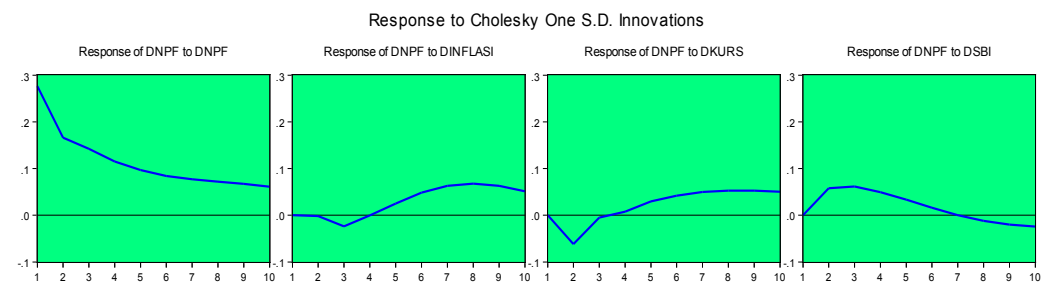


The graph 3, explains that FDR respond positive to movements the inflation in the short term until the 7 th period but after that FDR had a tendency to respond negative to inflation. FDR suffered shocks to the exchange rate in the short-term and has positive response but at 2 nd period until 3.5 period responded to the negative, then returned with a positive response at the 4th period and tend to have stability in 9 period. FDR's response positive to SBI untilat 5th period after that FDR respond with negative long-term and having stable negative respond to SBI.

Inflation give a stable respond at the beginning of the second period, after that NPF respond negatively to inflation shocks until the 4th period and thereafter gave a positive response, its mean the higher of the inflation rate will cause the greater the level of NPF. Exchange rate give negative effect to NPF untill third period, after that at the fourth period the movement of NPF as the respond of exchange rate is stable at posisitve respond. NPF respond positively to the shock caused by SBI until seventh period, after that NPF respond negativly to SBI.

\section{Graph 5. Impulse Response Function On ROA}

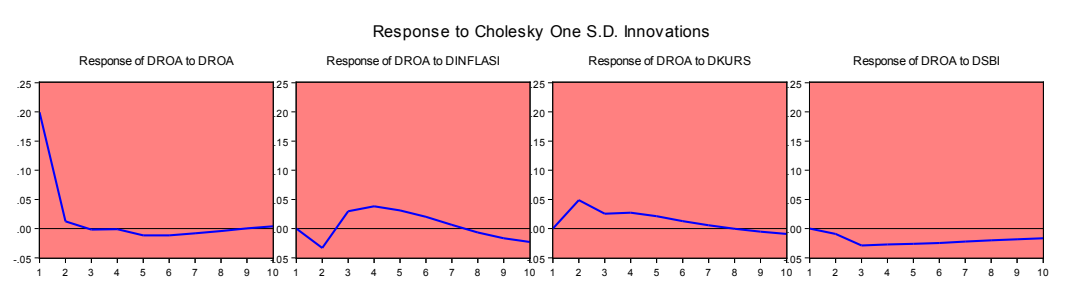

The graph above explains that the inflation gave negative shock to ROA but after second period, inflation tend to brought to the zero and ROA gives a positive response to inflation until the seventh period. Exchange rate Shock give positive effect on ROA and tend to be stable in the eight period after that ROA tend to negative respond exchange rate. SBI give ROA negative response and tend stable.

Table 3. Variance Decomposition Model (1) CAR

\begin{tabular}{cccccc}
\hline & \multicolumn{5}{c}{ Variance Decomposition of DCAR: } \\
Period & SE & DCAR & DINFLASI & DKURS & DSBI \\
\hline 1 & 1.336783 & 100.0000 & 0.000000 & 0.000000 & 0.000000 \\
2 & 1.402522 & 96.34677 & 0.999679 & 1.290292 & 1.363259 \\
3 & 1.564987 & 77.39283 & 15.34615 & 3.777673 & 3.483345 \\
4 & 1.718135 & 65.05940 & 27.45176 & 3.795459 & 3.693382 \\
5 & 1.804432 & 59.68344 & 32.93968 & 3.840892 & 3.535995 \\
6 & 1.853637 & 56.60407 & 35.79475 & 4.219619 & 3.381558 \\
7 & 1.884897 & 54.74216 & 37.36704 & 4.613230 & 3.277570
\end{tabular}




\begin{tabular}{cccccc}
8 & 1.903068 & 53.70180 & 38.09582 & 4.879719 & 3.322669 \\
9 & 1.914722 & 53.05528 & 38.37929 & 5.049229 & 3.516196 \\
10 & 1.924163 & 52.56504 & 38.50542 & 5.131814 & 3.797723 \\
\hline
\end{tabular}

From the result of variance decomposition on table 3, it can be seen that in the first period CAR is influenced by variables itself with a value of $100 \%$, in tenth periodCAR is influnced by its own variables at $52.56 \%$ and other variables affecting the tenth period CAR is the inflation rate effect $38.50 \%$, then the variable exchange rate effect of $5.13 \%$ and SBI whose give influence of $3.79 \%$.

Table 4. Variance Decomposition Model (2) FDR

\begin{tabular}{cccccc}
\hline \multicolumn{6}{c}{ Variance Decomposition of DFDR: } \\
Period & SE & DFDR & DINFLASI & DKURS & DSBI \\
\hline 1 & 2.814258 & 100.0000 & 0.000000 & 0.000000 & 0.000000 \\
2 & 3.405376 & 84.61833 & 0.210797 & 0.092497 & 15.07838 \\
3 & 3.668259 & 82.08140 & 0.448766 & 0.314167 & 17.15567 \\
4 & 3.743162 & 80.62526 & 0.560337 & 0.556163 & 18.25824 \\
5 & 3.762227 & 80.16739 & 0.715868 & 1.040097 & 18.07664 \\
6 & 3.790074 & 79.08602 & 0.753053 & 1.856415 & 18.30451 \\
7 & 3.828620 & 77.61979 & 0.750023 & 2.422237 & 19.20796 \\
8 & 3.875368 & 76.01495 & 1.058916 & 2.624580 & 20.30155 \\
9 & 3.935000 & 74.13494 & 2.129524 & 2.577904 & 21.15764 \\
10 & 4.013154 & 71.73056 & 4.159672 & 2.495334 & 21.61443 \\
\hline
\end{tabular}

From the table 4, it is known that variable FDR in the first period is influenced by the variable itself at $100 \%$, then the period of ten variables FDR is affected by the variable itself influenced by $71.73 \%$ and the second biggest variable whose gives influenced is SBI at $21.61 \%$. Further, inflation gives influenceat $4.1 \%$ in the period of ten and Exchange rate effect of 2.49 percent in the period of ten.

Table 5. Variance Decomposition Model (3) NPF

\begin{tabular}{cccccc}
\hline \multicolumn{5}{c}{ Variance Decomposition of DNPF: } \\
Period & SE & DNPF & DINFLASI & DKURS & DSBI \\
\hline 1 & 0.276172 & 100.0000 & 0.000000 & 0.000000 & 0.000000 \\
2 & 0.333364 & 93.52451 & 0.002483 & 3.455156 & 3.017851 \\
3 & 0.368386 & 91.48392 & 0.423766 & 2.847924 & 5.244388 \\
4 & 0.389198 & 90.71460 & 0.379816 & 2.590996 & 6.314587 \\
5 & 0.404310 & 89.79314 & 0.731620 & 2.935515 & 6.539726 \\
6 & 0.418169 & 87.97660 & 2.022665 & 3.743844 & 6.256896 \\
7 & 0.432684 & 85.32802 & 4.008094 & 4.819740 & 5.844142
\end{tabular}


Yoghi Citra Pratama: Macroeconomic Variable and Its Influence

\begin{tabular}{cccccc}
8 & 0.447077 & 82.50230 & 6.047942 & 5.901228 & 5.548534 \\
9 & 0.459898 & 80.09056 & 7.595677 & 6.878989 & 5.434774 \\
10 & 0.470083 & 78.34647 & 8.463037 & 7.726345 & 5.464146 \\
\hline
\end{tabular}

From the table 5 , it can be seen that the NPF variable is influenced by the variable itself by $100 \%$ in the first period and the second period NPF variable is affected by exchange rate at 3.45\% and SBI at 3.01\% and then inflation gives influence at $0.002 \%$. In the period of ten variables NPF influenced by variable itself by $78.34 \%$ and then followed by Inflation at $8.46 \%$, then the variable exchange rate influnced NPF at $7.72 \%$ and then SBI gives influence to NPF at $5.46 \%$.

Table 6. Variance Decomposition Model (4) ROA

\begin{tabular}{cccccc}
\hline \multicolumn{6}{c}{ Variance Decomposition of DROA: } \\
Period & SE & DROA & DINFLASI & DKURS & DSBI \\
\hline 1 & 0.199317 & 100.0000 & 0.000000 & 0.000000 & 0.000000 \\
2 & 0.208445 & 91.79469 & 2.538893 & 5.466057 & 0.200362 \\
3 & 0.214047 & 87.05893 & 4.309262 & 6.587490 & 2.044313 \\
4 & 0.220805 & 81.81397 & 7.030236 & 7.716723 & 3.439071 \\
5 & 0.225816 & 78.49478 & 8.614079 & 8.245917 & 4.645228 \\
6 & 0.228713 & 76.77743 & 9.181591 & 8.347609 & 5.693366 \\
7 & 0.230104 & 75.98051 & 9.143707 & 8.307620 & 6.568164 \\
8 & 0.231127 & 75.34009 & 9.147700 & 8.234731 & 7.277482 \\
9 & 0.232516 & 74.44299 & 9.549156 & 8.192048 & 7.815805 \\
10 & 0.234446 & 73.24785 & 10.34849 & 8.208393 & 8.195273 \\
\hline
\end{tabular}

From the table 6, it is known that the variable ROA in the first period is influenced by the variable itself amounted to $100 \%$ and then in the second period is affected by the exchange rate at $5.46 \%$. Further, it's influenced by inflation at $2.5 \%$ and SBI gives influenced to ROA at $0.20 \%$. In the tenth period ROA variable affecting itsself by $73.24 \%$, and further variable ROA influenced by inflation of $10.34 \%$ and the exchange rate amounted to $8.2 \%$ and the last SBI gives influenced to $\mathrm{ROA}$ at $8.19 \%$.

\section{Conclusion}

This empirical study provides several important findings; firstly based on analysis of impulse response function is known that the performance of the Islamic banking which are proxied by CAR, FDR, NPF and ROA had short-term shocks to macroeconomic fluctuations due to the financial global crisis. However, the performance of Islamic banking showed stable tendency in the long run. Secondly, 
based on the test of Variance Decomposition is known that the performance of Islamic banking which are proxied by CAR, FDR, NPF and ROA is affected by the variable itself in the first period and thereafter until the tenth period apparently Inflation provide second biggest influence to Islamic banking performance, it can be seen from its effect on CAR in the tenth period are giving out the effect of $38.5 \%$, and give influence $8.46 \%$ to NPF and $10.34 \%$ to ROA. Diffrent form others variables, the second biggest variables whose influenced FDR is SBI, whose gives the effect of $21.61 \%$.

The findings lead to the empirical conclusion that performance of Islamic banking is affected by fluctuations in macroeconomic variables in the short term but has a tendency to improved and stabilized quickly, this is because Islamic banking in running its operations related to the real sector, therefore the development of Islamic banking should be encouraged as much as possible in order to encourage economic growth and sustainable development.

\section{References}

Al-Qur'an dan Al-Hadist.

Athanasoglu, P.P. et.al. 2005. Bank-Specific, Industry Specific, and macroeconomic determinants of Bank profitability. Athens: Economic Research Department, Bank of Greece.

Ascarya. 2002. Instrumen-Instrumen Pengendalian Moneter. Jakarta : Bank Indonesia.

Bank of England. 2003. Assessing the Strength of UK Banks through Macroeconomic Stress Tests. Financial Stability Review, June, pp 91-103. England

Bank of Indonesia. Statistics of Islamic Banking. www.bi.go.id

Bank of Indonesia. 2012. The Development Acceleration Policy of Islamic Banking. www.bi.go.id

Bank of Indonesia. 2013. The Development Report of Islamic Banking 2012. www. bi.go.id.

Clair, R.S.T. 2004. Macroeconomic Determinants Of Banking Financial Performance And Resilence in Singapore. Singapore: Monetary Authority Of Singapore.

Gizycki, M. 2001. The Effect of Macroeconomic Conditions on Bank Risk and Profitability. Reserve Bank of Australia Discussion Paper No.06.

Gujarati, D.N. 2007. Basic Econometrics. New York: McGraw-Hill Education.

Mishkin, F.S. 2004. The Economics of Money, Banking, and Financial Markets (Seventh Edition). New York: Pearson Addison Wesley.

Nachrowi, N.D. \& H. Usman. 2007. Pendekatan Populer dan Praktis Ekonometrika untuk Analisis Ekonomi dan Keuangan. Jakarta: LP-FEUI. 